\title{
Key factors influencing Korean expatriates' and spouses' perceptions of expatriation and repatriation
}

\begin{abstract}
Lack of satisfaction with repatriation has been identified as one of the major causes for high turnover of employees returning from international assignments. Extant literature emphasises the importance of organisational training and mentoring, career advancement, and family and spouse support throughout expatriation and repatriation. In the current study we explored factors influencing Korean employees' and spouses' perceptions of expatriation and repatriation. The study involved semi-structured, in-depth interviews with 15 Korean expatriates and spouses, currently on assignment in Australia. The research is important in that, as Korea is Australia's fourth largest overall trading partner and Korean companies employ expatriates in managing their Australian operations, understanding factors which determine willingness of Korean expatriates to relocate to Australia is integral to Korean companies' position in the Australian economy. The findings provide three significant contributions. First, Confucian values affect Korean employees' willingness to expatriate and repatriate, in that their decision is largely influenced by requests from superiors. Second, Korean employees perceive that traditional expatriate training and mentoring are no longer as necessary given advances in technology. Third, Korean employees' decisions to expatriate and repatriate are affected by perceptions of impact on their children's education. The research highlights aspects particular to Korean expatriation and in so doing provides potentially valuable insights into Korean values regarding, and approaches to, international work.
\end{abstract}

Key words: expatriates, expatriation, Korea, policies, repatriation, spouse, willingness

\section{Introduction}

In pursuit of global competitiveness, organisations have increasingly adopted internationalisation strategies (van der Heijden, van Engen and Paauwe 2009; Vidal, Valle 
and Aragon 2008) which may have included decisions around how to effectively staff their global operations. While organisations utilise different types of employees in their staffing profiles, and recent research suggests a rise in the number of 'international commuters' and short-term international assignments as substitutes for the traditional expatriate assignment (Minbaeva and Michailova, 2004; Konopaske and Werner 2005), many organisations continue to utilise long-term expatriate assignees in their international operations. Over three decades of research has explored issues around recruitment, training, rewards and performance management associated with expatriation, with emphasis also placed on the importance of effective repatriation. Lack of satisfaction with repatriation has been identified as one of the major causes for high turnover of employees returning from international assignments (Black, Gregerson and Mendenhall 1992; Hyder and Lovblad, 2007; Stahl, Chua, Caligiuri, Cerdin and Taniguchi 2009).

The 2011 Brookfield Global Relocation Trends Survey Report (BGRS 2011) found that $95 \%$ of respondent organisations held repatriation discussions, $74 \%$ had written repatriation policies, yet only $14 \%$ had a formal repatriation strategy linked to career management and retention. The 2010 Survey (BGRS 2010) found that 38\% of repatriate employees resign from their company within the first year of returning home and another $22 \%$ leave within two years. There are clear costs for organisations from such turnover including having to appoint a new employee to the repatriate's position (Avril and Magnini 2007) and loss of skills and knowledge acquired by the repatriate on the international assignment - which may result in an opportunity for other organisations to gain competitive advantage (Crowne 2009). Importantly, high turnover of repatriated employees, and perceptions of increased uncertainty and risks associated with taking international assignments, has been suggested to result in other potential expatriates being reluctant to accept international assignments (Borstorff, Harris, Field and Giles 1997). 
While some of the literature has viewed expatriation and repatriation as two separate processes, Avril and Magnini (2007) highlight the importance of seeing expatriation from a holistic viewpoint, which they identify as including different stages of the assignment. These stages are selection, training, organisational support, and repatriation, although they emphasise that organisational support is crucial throughout. Effective management of global human resources throughout repatriation needs to include not only organisational training, but also mentoring, career advancement, and family and spouse assistance with readjustment (Tung 1998a; Suutari and Brewster 2003; van der Heijden et al. 2009). In the current research we explored key factors influencing Korean expatriates' and spouses' perceptions of expatriation and repatriation.

The rationale for focusing on Korean expatriates was based on Korea being Australia's fourth largest overall trading partner (DFAT 2011) and that as Korean companies employ Korean expatriates in managing their Australian operations, understanding factors which determine willingness of Korean expatriates to relocate to Australia and then repatriate, is vital to the success of Korean companies' position in the Australian economy. This research finding may also have implications for Korean business success in other nations. Unlike some of its Asian neighbours who continued to suffer economically following the financial crisis of the late 1990s, Korea has grown in global positioning through strong economic development (Mah 2007) with Korean conglomerates, such as Hyundai, LG, Samsung, Kia and Daewoo, taking advantage of their competitiveness in the global market (Choi, Michell and Palihawadana 2008).

The findings of this research are based on 15 semi-structured, in-depth interviews with Korean expatriates and spouses, and address the following overarching research problem:

What factors influence Korean employees' and spouses' willingness to accept and repatriate from international assignments? 
This article begins with an overview of the largely Western literature on expatriation and repatriation. Following this, a discussion is provided of Korean characteristics and how expatriation and repatriation may be viewed differently from the Korean perspective. This is followed by presentation of the methods, findings and discussion. The article concludes with key contributions, implications and issues for future research.

\section{Literature Review}

Long-term expatriate assignments incur high costs and substantial planning to ensure successful adjustment of expatriate employees and to minimise failure (Collings, Scullion and Morley 2007). Challenges identified in the (largely Western) literature include: expatriate non-adjustment (Lee 2005), lack of job satisfaction (Bonache 2005), lack of career advancement (Kraimer, Shaffer and Bolino 2009; Stahl et al. 2009), lack of organisational support (Lazarova and Cerdin 2007) and family and spousal non-adjustment (Brett and Stroh 1995; Larson 2006). As international assignments require expatriates (and often accompanying spouses and family) to relocate to a foreign environment, there is always a high risk of uncertainty and stress. Therefore, support is important, and it has been suggested that support before, during and after the assignment helps to minimise uncertainty for expatriates (Borstorff et al. 1997; Lazarova and Cerdin 2007). Yet, it has also been argued that organisations neglect the continuous support that is essential (Dupuis, Haines and Saba 2008).

There are numerous work-related adjustment issues that must be addressed for expatriates including job and organisational factors (Andreason 2003). Non-work related adjustment is also critical to success and contributes to reducing the uncertainty and anxiety felt by expatriates. Adjustment has been categorised as psychological and socio-cultural, with psychological adjustment referring to expatriates' individual contentment in the new culture 
and socio-cultural adjustment referring to expatriates' ability to interrelate with host culture members (Ward and Kennedy 1996).

\section{Organisational training and mentoring support}

Expatriate training involves educating expatriates about cultural, language and lifestyle differences in the host country and assists in minimising the barriers to adjusting to the host country (Chen and Chiu 2009). Mentoring involves the expatriate's relationship with a more experienced organisational member from which the expatriate is able to gain organisational knowledge, increase adjustment, reduce work and non-work related stress, and increase their ability to achieve goals (Carraher, Sullivan and Crocitto 2008). Baugh and Sullivan (2005) suggest that having both a home and host country mentor will enhance expatriate effectiveness. Expatriates' expectations of organisational support are fulfilled by adequate lead time to prepare for the assignment (Haslberger and Stroh 1992), mentoring to ensure well-being and home country events being communicated regularly (Feldman and Thomas 1992). Though researchers identified explicit organisational support processes to be of great importance to expatriate employees (Aryee, Chay and Chew 1996) and enhance the psychological contract (Woo and Ang 2011), many cases have recognised that lack of organisational support leads to assignment failure (Borstorff et al. 1997).

\section{Career advancement}

Expectations of career advancement following successful international assignments are said to be one reason why potential expatriates accept assignments (Doherty, Dickmann and Mills 2011; Haines and Saba 1999). The expectation is that an international assignment will benefit expatriates with opportunities for learning and development perceived as being constructive

for continued career advancement (Gregersen and Stroh 1997; Kamoche 1997; Leiba- 
O'Sullivan 2002). The perception that the international assignment will enhance job satisfaction in subsequent positions, whether in the same company or another, has a positive relationship with expatriates' intentions to accept international assignments (Hinsz and Nelson 1990; Suutari 2003). Yet, career advancement upon return does not always match expectations (Bossard and Peterson 2005) in that expatriates are not always promoted upon return and rarely is newly acquired knowledge and skills appreciated by organisations (Caligiuri and Lazarova 2001). Such obstacles mean that potential expatriates may be reluctant to accept international assignments (Selmer 1999).

\section{Family and spouse}

Willingness of the family to relocate has a positive influence on expatriate employees' willingness to accept international assignments (Tharenou 2003; Dupuis et al. 2008). Failed expatriation due to family problems can be the reason behind potential expatriates' reluctance to accept future international assignments (Gillian 1996). Van der Zee, Ali and Salome (2005) state that family non-adjustment can have a crossover effect and negatively influence expatriates whilst on assignment. Similarly, expatriates' inability to adjust can also influence their families. Although research has identified the importance of selecting and training the family and spouse prior to relocation, sufficient preparation is not provided to the family by organisations (Larson 2006). An increase in dual-income families has led to the issue of whether the partner will be able to find a job in the host country that meets both income and job satisfaction expectations (Gillian 1996). Challenges are presented for dual career couples where a spouse is ineligible to work in the host country or unable to find suitable work. Spouse job assistance is an important factor affecting potential expatriates' willingness to accept international assignments (Konopaske and Werner 2005). Other research suggests that accompanying spouses not only desire job-related support and career counselling, but also 
compensation for loss of salary (45\%) and assistance with educational opportunities (38\%), which are rarely provided by organisations (Riusala and Suutari 2000), but could be expected to make an international assignment more attractive.

\section{Repatriation}

Despite the majority of research about international assignments being based on expatriation prior to, and during the actual assignment, increasing research has identified the crucial nature of repatriation for the success of the overall overseas operation (Kim 2005). Turnover of repatriates following international assignments is a major problem for organisations in that failure to retain such repatriates can result in a major loss of cross-cultural skills and knowledge in which the company has invested, which might have proved a basis for establishing competitive expertise (Bossard and Peterson 2005; Lazarova and Cerdin 2007). The major reasons for repatriated expatriates leaving their organisation are: lack of organisational support (Jassawalla, Connelly and Slojkowski 2004; Hyder and Lovblad 2007; Lazarova and Cerdin 2007); ambiguity about, and non-existence of, career advancement (Jassawalla et al. 2004; Hyder and Lovblad 2007; Kraimer et al. 2009; Stahl et al. 2009); and inability of the family/spouse to readjust to the home country (Hyder and Lovblad 2007).

\section{Organisational training and mentoring support through repatriation}

Lazarova and Cerdin (2007) have argued that the reason behind the repatriation 'exodus' is lack of organisational support communicated to expatriate employees before, during and after assignments. Perceived organisational support during expatriate assignments is negatively

related to repatriates' intention to leave the company or seek alternative career options (Jassawalla et al. 2004; Hyder and Lovblad 2007; Lazarova and Cerdin, 2007; Stahl et al. 2009). Organisational support programs that accommodate repatriates' needs, such as training 
prior to repatriation, mentoring, and pre-departure agreement on the position in which the expatriate will be placed upon return, have been viewed as influencing expatriates' perception of organisational support (MacDonald and Arthur 2005; Lazarova and Cerdin 2007) and might be expected to influence willingness to relocate.

\section{Career consequences on repatriation}

Although $33 \%$ of repatriates believe that international assignments provide the opportunity to receive a promotion more quickly (BGRS 2010), repatriates find that returning home is far more difficult than expected (Bossard and Peterson 2005). Studies on repatriate job satisfaction highlighted that most satisfied repatriates were working in positions that allowed them to utilise newly acquired knowledge and skills and, vice versa, dissatisfied repatriates criticised their organisation's career management system as not recognising and valuing their acquired international knowledge and skills (Feldman and Thomas 1992; Lazarova and Cerdin 2007).

Repatriates may feel anxious and uncertain about career advancement opportunities on return (Yan, Zhu and Hall 2002). Kraimer et al. (2009) argued that recognising knowledge and skills acquired from the international assignment and promotion upon repatriation reduce anxiety, thus reducing repatriates' intention to resign. Vidal et al. (2008) concluded that having an effective professional career management system that is made apparent to expatriates before and during assignments is positively related to satisfaction with the repatriation process; also reducing the intention to resign.

\section{Family and spouse and repatriation}

Organisations easily overlook readjustment as they perceive 'coming home' as a comfortable process that is simple and effortless (MacDonald and Arthur 2005). However, the expatriate 
and their family are deemed to have embraced a different culture in a different environment with different people encountering different experiences, thus becoming a different person valuing a different culture (Gregersen and Stroh 1997). Family and spouse readjustment on repatriation is just as important as minimising stress and anxiety on expatriation (Larson 2006). By reducing the uncertainty, risks and anxiety involved in family repatriation through guaranteeing assistance with readjustment training and job support, the gap between perceived support and actual support can be reduced (Lazarova and Cerdin 2007) and might be expected to influence the willingness of potential expatriates to accept international assignments.

Given increasing numbers of dual-career couples, it is not only expatriates that need to be guaranteed post-assignment career management. It is also important for spouse/partners to be aware of any assistance organisations provide in job finding in the home country and whether they will be able to return to a lateral or promoted job and comparable income (Harvey and Wiese 1998). But it has been found that there are many companies that still overlook the positive influence that career support will have on spouse adjustment (Harvey and Wiese 1998).

\section{Korea and Expatriation}

The majority of research on expatriation focuses on the experiences of Western expatriates. It has been suggested that non-Western expatriates will also face challenges in adapting to unfamiliar contexts and the majority relocate to Western, industrialised countries, rather than other developing countries (Wood and El Mansour 2010). The following section therefore questions the literature on expatriation from the Korean perspective by reference to Korea's cultural values. 


\section{Hofstede's cultural dimensions and Confucianism}

Korean cultural values may provide a foundation for understanding expatriation/repatriation in the Korean context, and thus assist with interpreting the largely Western literature through a Korean lens. Utilising Hofstede's (1980) and Hofstede and Bond's (1988) dimensions, Korea has been categorised as having high collectivism, a large power distance, a low acceptance of uncertainty, high masculinity and a long-term orientation; with Confucianism the fundamental philosophy behind Korean culture (Hofstede and Bond 1988). Employees in cultures that possess high power distance and high collectivism have been perceived to accept positions that are requested by superiors or colleagues, are expected to be more committed to current jobs (Gray and Marshall 1998), and accepting of autocratic leadership styles and a group focus (Yang 2006). There is a vertical flow of decision making authority at the senior management level within Korean companies (Morden and Boweles 1998) and this distinct hierarchy within Korean organisations is argued to derive from such valuing of authority (Yang 2006). Often the owner of a company is referred to as the 'king' and has complete decision making power (Shik 2004). The Confucian work ethic known as sincerity, as well as the will to achieve and succeed, and emphasis on sacrificing in the company's favour are values embedded in Korean organisations. Moreover, expectations of loyalty and allegiance have provided the foundation for employees' full subordination to superiors (Kim and Park 2003). As seniority is highly emphasised in Korean Confucianism, decisions made by superiors are rarely questioned and orders have been regarded as mostly accepted to ensure the Confucian value of conflict-free relationships (Paik and Sohn 1998). Conforming to expectations of superiors has been argued to be essential and maintaining beneficial

relationships with superiors is considered more important than concentrating on the self (Yang 2006). 
It has been suggested that in Korea's high context society, Koreans tend to be risk adverse and, at work, find it difficult to take risky positions and make individual decisions. As such, in organisations actions are often taken by committees so as not to draw attention to one individual for a poorly made decision (Gannon \& Pillai, 2010). Yet, other research has suggested that Koreans will take risks and because of the collectivist culture, individuals will be more pro-risk when acting in groups. Indeed it has been suggested that extreme risks have been pursued by Koreans focused on group conformity and this has resulted in unwanted side-effects in organisations, such as in the late 1990s financial crisis (see Kim \& Park, 2010) - although it has been noted that such events have left some older Koreans wary of risk taking behaviour (Chafkin, 2011). While economic growth in Korea has been based largely on tradition and Confucianism and the family-owned conglomerate chaebols, there are calls for young Koreans to move away from a focus on the stability of being a 'salary man' and to running their own businesses and being more entrepreneurial (see The Economist, 2011). Indeed, it has been argued that in Korea there is a continuing contrast in the pull of history and tradition and the push of globalisation.

\section{Korean expatriate's willingness to accept international assignments}

Korean employees could be expected to accept assignments if requested by superiors as the relationship between employer and employee, founded upon Confucian values, suggests compliance by employees towards their superior is valued (Paik and Sohn 1998). Furthermore, employees in this culture may be uneasy with refusing their superior's orders and perceive refusal as risking their jobs and ruining their relationship with their superior (Yang 2006). Therefore, it can be argued that many potential Korean expatriate employees will take an international assignment, regardless of their willingness to expatriate. It can also be argued that they will then repatriate out of loyalty to their superiors, even if they did have 
other options such as to repatriate to a different organisation or stay in the host country. This leads us to present the following research questions:

Research Question 1: Are Korean employees more willing to accept an international assignment when requested by their organisation?

Research Question 2: Will Korean employees repatriate from an international assignment when requested by their organisation?

\section{Repatriation management in Korea}

Korea is said to possess high levels of uncertainty avoidance, indicating that Korean society is reluctant to accept ambiguity and change (Hofstede and Bond 1988). Therefore, in order to motivate Korean employees to take international assignments it can be suggested that uncertainty and anxiety must be reduced. As Kim (2005) reported, Korean repatriates who are satisfied with the overall repatriation management of their organisation will successfully be able to readjust to their jobs; thus having a positive influence on other employees as potential expatriates in the organisation.

Organisational training and mentoring for Korean expatriates

Employees in Confucian societies such as Korea have been regarded as valuing employeremployee and superior-subordinate relationships where superiors look after subordinates' well-being in both work and non-work settings in return for obedience and loyalty (Rhee 2002). Hence, formal communication from the home country organisation ensures Korean expatriates are aware of what is occurring in the home country and this has a positive influence on the work-readjustment process (Kim 2005). Therefore, communicating to potential Korean expatriates what to expect on return, through relocation training and support and mentoring, prior to the commencement of expatriation, would be expected to have a 
positive influence on expatriates' willingness to accept international assignments. This leads to the following research question:

Research Question 3: Are Korean employees more willing to accept an international assignment if, prior to commencement, they are informed of the training and mentoring that the organisation will provide on repatriation?

\section{Career advancement for Korean expatriates}

Uncertainty in regards to expatriates' career advancement on return would be expected to be a particular source of stress for employees in high uncertainty avoidance cultures, such as Korea. Hwang (2006) reported that for Korean expatriates, satisfactory career management was positively related to job adjustment, thus allowing organisations to retain repatriates. Therefore, pre-determining the existence of such management to expatriates prior to their assignment would likely anticipate successful job adjustment and job satisfaction on return. Additionally, Rhee (2002) argued that individualistic characteristics are also evident amongst employees in Korea and therefore it is not possible to solely rely on Hofstede's (1980) dimensions to evaluate the cultural characteristics of Korean employees. Previous studies have shown that Koreans' career success orientation holds different values depending on age and years of experience: younger generations with less work experience value work and life balance, whilst older generations with over ten years experience place much emphasis on job security (Kim and McLean 2008). Therefore, it could be expected that Korean employees may be more favourably disposed towards accepting international assignments where it is perceived that career advancement opportunities will result. This leads to the following research question: 
Research Question 4: Are Korean employees more willing to accept an international assignments if, prior to commencement, they are provided with a guarantee of career advancement following repatriation?

\section{Family and spouse of Korean expatriates}

Confucianism stresses the importance of a loyal relationship between the family and familial piety (Taormina 1998). Further, strict obedience towards decisions made by the head of the family, the father, is valued in Korean society (Jaw, Ling, Wang and Chang 2007). Previously, a majority of the Korean workforce comprised males and only men were offered expatriate assignments. Women believed their job was to take care of the household and children and were rarely recruited to jobs that would require managerial positions (Kang and Rowley 2005) or international assignments. However, changing social values in Korea have resulted in many more women in the workforce (Byun, Baek and Kim, 2001) and dual-career couples are increasing (Kang and Rowley 2005).

Therefore, the support given to the family upon repatriation would likely be regarded as important. Failure to consider family readjustment issues will lead to repatriates' negative perception of organisational support (Dupuis et al. 2008) and is likely to be especially so in family-focused Confucian cultures, such as Korea. Therefore, guaranteeing a family adjustment program, prior to the commencement of expatriation, is likely to positively influence employees to accept an assignment. This leads to the final research question:

Research Question 5: Are Korean employees more willing to accept an international assignment if, prior to commencement, a family adjustment program for repatriation is outlined? 


\section{Method}

This research utilised a qualitative research design which was deemed most appropriate for the questions under examination. There are potential threats to the value of qualitative research such as researcher bias, and limited generalisability of findings (Maxwell, 2005), along with sample size relative to quantitative studies, and limitations of qualitative research in an international context, specifically, such as what Birkinshaw, Brannen and Tung (2011) refer to as conceptual abstraction which provides only partial understanding of contextual differences. Yet, there are many valuable benefits of having a qualitative approach to gathering and analysing data in international business and management. Notably, it has been suggested that qualitative research may assist with more nuanced understanding of fundamental constructs in international business such as culture, the interplay between culture and context, and understanding individuals collaborating across cultures (Birkinshaw, Brannen, \& Tung, 2011). Further, Doz (2011) suggests that qualitative research is uniquely suitable because of such factors as: ability to open the black box of organisational processes in relation to issues of how, who, and why; theory testing ability; providing for rich, thick description; opportunity for learning about context up close; and more likely opportunities for discovering new phenomenon.

This research utilised 15 semi-structured, in-depth interviews with nine Korean managers currently employed on an international assignment in Australia and the spouses of six of the managers. In-depth interviews were selected as they are effective where there is limited information and knowledge on the area of research and it is essential to extract information from each participant's experiences that will assist in generating new knowledge and addressing a gap in the literature (DiCicco-Bloom and Crabtreee 2006; Hesse-Biber and Leavy 2011).

Purposive, judgemental sampling was used as it involves choosing subjects who are 'in the best position to provide the information required' (Sekaran and Bougie 2010, p. 277) and allowed for time constraints in contacting and collecting data. A publicly available list of 27 Korean companies currently operating in Australia known to be employing expatriate 
Koreans was obtained through a public agency that promotes trade and investment for Korea. The agency did suggest that there may be a few companies not listed and a few who had previously had an expatriate manager who had not yet been replaced. It should be noted that it is difficult to gain details of all Korean companies in Australia and to achieve access for research purposes, due to confidentiality concerns of Korean companies. The list included contact details for a Korean expatriate employee in each company in a large variety of industries including manufacturing, electronics, transportation equipment, tourism, investment and trade. The whole list was chosen for this study and despite the significance of the Australian economy for Korea, there are only a small number of Korean companies in Australia; therefore the sample size was small.

The research was conducted in accordance with university ethics. The 27 contacts were e-mailed explanatory letters and consent forms in English and Korean. Of the 27 contacts, nine expatriates from eight companies (a 33.33\% response rate) agreed to participate. Another group of interviewees were selected for post hoc analysis: the accompanying spouses of the expatriates. Of the eight accompanying spouses (one expatriate did not have his wife accompany him), six agreed to be interviewed. Wiesner and Cronshaw (1988) argue that post hoc analysis improves interview reliability. The decision to interview the spouses was based on preliminary findings from expatriate interviews suggesting that family issues and spouse perspectives needed further investigation. An explanatory letter and consent form was also provided to the spouses.

\section{Sample}

The size of the head office varied amongst the expatriates' organisations. Sales ranged from AUD $\$ 40$ million to AUD \$40 trillion and workforce numbers worldwide ranged from 450 to over 50,000 employees. The estimated percentage of employees currently assigned to an 
international subsidiary ranged from $0.7 \%$ to $25 \%$ of the total. Of the expatriates, all were male and married and eight had an accompanying spouse and children on assignment in Australia. The expatriate without an accompanying spouse did not provide any details about why his wife remained in Korea. Only three of the expatriates had previous international assignment experience. The duration of expatriates' current assignments was approximately four years. Demographic information about the expatriates is outlined in Table 1. The eight accompanying spouses were contacted to participate in an interview and six agreed to do so. Of the six spouse interviewees, three had previous experience with international assignments (accompanying their husbands). Furthermore, three were working at the time of the request to undertake the international assignment but none were working while on assignment in Australia. Demographic information about the spouses is detailed in Table 2.

[Insert Table 1 about here]

[Insert Table 2 about here]

\section{Procedure, interview questions and analysis}

Telephone interviewing was used as face-to-face interviews were not suitable given the various locations of interviewees. The option of an e-mail interview was only presented where the participants expressed reluctance or difficulty communicating by telephone. This approach was used for one expatriate and one spouse, and the answers were confirmed via follow-up telephone interview. The telephone interviews were recorded in Korean, translated into English and back-translated by another bilingual speaker to ensure accuracy, as is recommended by Brislin (1980). Results were analysed in English. The interview data were scripted and themed manually. Themes were identified through categorising the data in 
relation to the five research questions. Additionally, the post hoc analysis was conducted with six of the eight accompanying spouses to support or contradict themes arising in relation to family and spouse support. Direct quotes from interviewees were included in the findings to assist judging transferability to other contexts. The quotes from interviewees were produced verbatim given that it has been suggested that preserving and respecting the voice of participants is fundamental in qualitative research irrespective of any structure or analysis which researchers may impose on findings (see Lee, 1999; Yin 2011).

Expatriate interviews included nine major components: organisational information; willingness to expatriate; company repatriation program; perceived training and mentoring; perceived career advancement for repatriates; perceived family and spouse assistance for repatriates; willingness to repatriate; willingness to accept future international assignments, and demographics. Spouse interviews included six major components: perceptions of the international assignment; relocation experience, perceived organisational support; views on international assignments; views on repatriation, and demographics.

\section{Findings}

This section is organised around factors influencing Korean expatriates' and spouses' perceptions of, and willingness to, expatriate and repatriate as follows: reasons for accepting the assignment and repatriating, organisational factors, career advancement, cultural factors and family factors.

\section{Reasons for accepting an assignment and repatriating}


In terms of the main reason for accepting the international assignment, three expatriates (Interviewees 1, $6 \&$ 7) responded that it was a good opportunity for career development. However, Interviewee 6 stated that:

\begin{abstract}
"Previously if you worked overseas and returned you would receive a promotion and there were a lot of benefits you received - like given a preferential treatment for promotion. However these days staff that stay at the head office seem to be promoted more and how can I put it... the style is changing now? It is not good to go overseas" (Interviewee 6).
\end{abstract}

Nevertheless, he suggested that when the assignment was accepted the main reason for his decision was promotion. Interviewee 9 said he accepted the assignment to gain international experience. Four interviewees responded that they did not have particular reasons for accepting the international assignment, but rather that their company instructed them to go (Interviewees 3, 4, 5 \& 8).

Most of the expatriates' spouses/families had positive feelings when chosen for the assignment because they understood the nature of the work (Interviewee 3), it was perceived as a good educational opportunity for the children (Interviewee 2), the wives had previous experience studying abroad (Interviewees $1 \& 6$ ), or the family was keen to live abroad (Interviewees 5, $8 \& 9$ ). The spouse of Interviewee 7 was happy when the interviewee was chosen for the assignment but did not accompany him to Australia. Only the family of Interviewee 4 had felt a sense of inconvenience, however they accepted with good will as it was company policy.

All of the expatriates' companies communicated a timeframe for the assignment. However, only one expatriate's company had a repatriation program and it was not a standardised program for all employees. The three interviewees whom had undertaken an international assignment prior to the current assignment (Interviewees 3, 5, and 9) also stated 
that such programs were not provided but there was some relocation logistics support available. Although most interviewees felt no need for a repatriation program, Interview 6 seemed surprised that such programs were provided in other companies:

"There are companies that have these programs?" (Interviewee 6).

Two expatriates did not understand the concept of repatriation programs (Interviewees 1 \& 2). However, they stated that the company did provide logistics support (assistance with transport and moving). Interviewee 3 explained that although his company used to have repatriation programs, his organisation no longer utilised them. This was a first international experience for six of the interviewees, who mostly expressed no need for repatriation programs. Yet, they have not repatriated and therefore it seems likely they would not have realised the challenges they might experience on repatriation and as such may not recognise the need for organisational repatriation support.

When asked whether they were willing to return to their current company after completing their assignment, eight interviewees responded that they were willing to do so. Interestingly, the only reason given by Interviewees 3, 8 and 9 for returning to their current company was because there were no alternatives for them for which it would be worth changing organisations. Apart from Interviewee 6, all other expatriates answered that they would have to return to their home country. The reason behind Interviewee 6's decision not to repatriate to Korea was his concern for his children's adjustment to Korea's education system.

"The main reason is the children's education. If the company had a repatriation program for the children to help them readjust to Korea, such as assistance with enrolling them in an international school or such then that would change my decision but without that assistance I do not wish to repatriate” (Interviewee 6).

When the trailing spouses were asked about their feelings at the time their husbands were requested to accept the assignment, all six responded that they had positive feelings, noting the reason as being the location of the assignment in Australia. Three spouses 
perceived coming to Australia as a good opportunity for their children's education and one spouse (who did not have children at that time) felt that having a child in Australia would be beneficial. Interestingly, three of the six spouses were working at the time but resigned to accompany their husband. Their husbands decided it would be best for the family to be together and the wives were willing to follow:

"My husband emphasised that the family should be together and so we decided to follow his decision." (Interviewee 10 - Spouse).

Furthermore, the main concern for most of the trailing spouses was the wellbeing of their children and combined with the lack of language competencies it seemed the trailing spouses were not concerned with their employment in Australia.

In regards to repatriation, all but one spouse responded that they would repatriate to Korea if this was decided by their husband. One spouse indicated that she was reluctant to repatriate:

"My children are definitely Korean but they were raised with a very different way of thinking in a very different environment so I can guarantee that they will have problems...... I would rather prefer to go to another English speaking country like England or even Europe." (Interviewee 13 Spouse).

Although the rest of the spouses expressed a willingness to repatriate, they too feared for their children's ability to cope with living in Korea. They felt that their children considered English to be more convenient than Korean and that they may not be able to adapt to the difference in lifestyle between the two countries. 


\section{Organisational Factors}

Work related training was provided for three expatriates (Interviewees 3, 5, \& 6). Two expatriates did not receive expatriate training as they had limited notice of the assignment and had insufficient time to prepare (Interviewees $2 \& 4$ ). However, they said that their company usually provided expatriate training. They did not indicate that they experienced any difficulty with working on the assignment without such training. Whilst Interviewee 2 also stated that his company provides language training, Interviewee 5 argued that:

"The company sends expatriates who can already speak the language and therefore there isn't any language training." (Interviewee 5).

Of the four expatriates with no expatriation training, three commented that there was no need for it because the company selects employees who are already competent to carry out the duties (Interviewees $1 \& 9$ ), and expatriation is perceived as an extension of work conducted in the home country (Interviewee 6). This suggests that the emphasis in any expatriate training is on the technical aspects of the job rather than cross-cultural competencies. Overall there was limited evidence of non- work related expatriation training.

Repatriate training had no influence on seven of the expatriates' decisions to accept the assignment (Interviewees 1, 2, 3, 4, 5, 8, and 9). An interesting reason behind these responses was advancements in technology which some expatriates perceived as closing the gap between national and international work. For example, one interviewee commented:

"The internet is so advanced today that the communication flows very quickly. Also, technology has allowed for travel between countries to be shorter. The gap between national and international is continuously closing to an extent where going abroad isn't such a difficult move anymore. The need for repatriation training therefore is reducing with the continued advancement in technology. You can find all the information you need online." (Interviewee 3). 
When questioned about the provision of a mentor, eight expatriates said that they did not have an official mentor. Of these, three commented that whilst a mentor is not formally assigned, they were able to communicate with their predecessor who acted as an informal mentor. It should be noted that while mentoring has taken on increasing importance in Western organisations, such a model may not necessarily be appropriate in the Korean context in which a superior-subordinate relationship, emphasis on hierarchy and power distance means that decision making is still very much top down. Accordingly, while in a Western context expatriates may take advice from peers or even subordinates who had prior international experience, power relationships in Korea might necessitate that advice would only officially be received from management in a senior position; hence maintaining the integrity of the superior-subordinate relationship. Such informal mentoring might be expected to occur given the extent of superior-subordinate socialisation in Korean organisations and whilst this may not translate into assistance with cross-cultural relocation, emphasis is likely to be placed on the role of the superior in facilitating the knowledge of the expatriate about technical aspects of the role.

Interviewee 2 responded that his company did not provide a mentor but there was an online portal. As he said:

“There's a portal site. Because every international assignment differs in country and culture, the expatriates after their 4 years of expatriation must share their experiences and know-how's through this portal. If I upload the knowledge and tips accumulated through my assignment then this becomes the database and those expatriating after me can open the relevant files and collect information. As time goes by the information accumulates and acts as a mentor.” (Interviewee 2).

Interviewee 1 commented on the company's intranet systems and real time communication, which allowed for information to be received the instant it was sent. This, it was suggested, enabled repatriates to acculturate back home and therefore repatriation 
mentoring was not deemed necessary. Overall, mentoring for repatriation appeared to have limited influence.

\section{Career Advancement}

All expatriates responded that their company did not communicate intended career progression following the assignment, or prior to taking the assignment. Six agreed that career advancement was based only on accumulating performance points, which was defined as including the number of successful achievements of project/department/organisational goals and the number of years employed in the company. Interviewees 7 and 8 elaborated by explaining that once regarded as having sufficient performance points to reach the next level for promotion, the employee entered a pool of promotion candidates. As one expatriate commented in relation to this pool:

"The company prefers someone who they can actually see. Not everyone in the pool will be promoted so going abroad at that time could be a disadvantage." (Interviewee 8).

The negative impact of international assignments on career advancement was agreed on by Interviewees 6 and 9. The former argued that when an employee expatriated, the new position that they needed to enter may be filled by another employee and therefore there may be no vacant position left for the repatriate - they would have to either return to their original position if it was still vacant or be assigned to another department.

Four expatriates indicated that career advancement was an important matter in their expatriation or repatriation. Interviewee 2 expected it to have a positive influence on his career. Interviewee 6 explained that career advancement was not an important factor as the expatriates usually entered a higher position in the host country. However, it was an issue that could not be addressed lightly when repatriating, as most of his colleagues may have been promoted in the home country whilst he was on the assignment. An interesting response came from Interviewee 8, who stated: 
"I guess it's important. If you are to work long term at a company then unless you are promoted you can't work there for a long time. I think there will be a bit of influence when accepting an international assignment. But even though there isn't any guarantee of career advancement, it's a risk that I must take. Employee's willingness isn't reflected in the company's decisions. If the company says go, you go." (Interviewee 8).

The translation of 'career' in this context refers to having a secure occupation rather than focusing on the traditional Western notion of promotion. Personal career was deemed important when accepting an assignment by three of the 9 interviewees. Interviewee 2 stated that the most important issue is whether or not the assignment influenced developing his personal career by assisting him to develop his current job and reach his expected goals within the organisation. Interviewee 4 responded that he viewed international assignments positively as he believed that experience gained whilst on an assignment contributed to developing individual abilities and career prospects. Interviewee 4 perceived the experience and skills attained through the assignment would contribute to building his career beyond his current company. Interviewee 5 also stated that developing a career along with location, was important in an international assignment.

Interviewee 6 assumed the company made the decision about location based on the company's preference for the employee. His perception was that the company did not send a competent employee to a less developed country. He believed that expatriates did not wish to go to less developed countries for three reasons: the perception that the company does not send the best employees to less developed countries; the lower standard of living compared to developed countries; and the difficulty of achieving results in those contexts. Interviewee 6 added that there were several cases where employees resigned from the company when they were requested to expatriate to less developed countries. 


\section{Cultural Factors}

In terms of acculturation, the response from four of the nine expatriates was that advanced technology in today's global world enables quick communication flows, further reducing the gap between national and international work (Interviewees 1, 3, 6 \& 7). Interviewees 1 and 3 both felt that their work was the same regardless of whether it was located nationally or internationally. Interviewee 3 pointed out:

“Especially in today's society where so much knowledge is shared online, the difference in culture and lifestyle is narrowed down." (Interviewee 3).

However, Interviewees 3, 6 and 7 emphasised the importance of their companies giving consideration to the host country's culture in terms of non-work issues rather than focusing only on work related aspects. Interviewee 3 stated that whilst his company previously provided assistance for dealing with cultural differences, real time communication and advanced technologies were contributing to the removal of such programs and yet there was a need for the company to take the differences into consideration when developing internationalisation strategies. Interviewee 7 extended this though by adding that without the background knowledge of the host country's culture, the expatriate may find himself detached from his local colleagues and would not be able to interrelate effectively.

Interviewee 6 elaborated by saying that although there seemed to be a reduced gap between countries with advancements in technology and real time communication, the body and the mind still experienced differences in practice and therefore needed help to live and work within the host country culture and readjust to Korea. Interviewee 6 gave the following example:

\footnotetext{
"For example, Australia is a very laid back country compared to Korea and although I know that Koreans are more fast paced, it is still different for my body and mind to readjust back to the old ways. I feel the difference even when I return to the country for a short time during my expatriation." (Interviewee 6).
} 
This suggests that Interviewee 6 is expecting to experience adjustment issues during his repatriation. In contrast, one of the spouse comments in response to the question of whether organisational support was deemed necessary was:

"Well no because we are able to find all the information on the internet and keep in close touch with the new trends and culture so I don't think there's a need for any support for repatriation." (Interviewee 12 - Spouse).

The view of interviewees (both expatriates and spouses) was that the availability of cultural and relocation information on the internet and advancements in technology not only assisted with work related adjustment but also non-work related adjustment.

\section{Family factors}

All expatriates responded that there was no repatriation program for their families apart from logistics support. Since there were no family repatriation programs it is hard to ascertain their influence, but it seems even if they did exist the influence would be limited. Interviewee 2 elaborated that his company would provide financial support for his family to stay in the host country if the children were in the middle of a semester at school when the expatriate is required to repatriate to the head office. Another interviewee commented:

"For example, if children come out during grade 1 and return at grade 6, the academic education level differs greatly. Students who study here would be fools when they return to Korea. So many expatriates leave their family here when they repatriate. It would be fine if the children were older and in high school because then there's the benefit of learning English and they are able to catch up with the home country education level as they go. But if the children are younger, it's a negative impact for the children to return them back home. They cannot adjust well." (Interviewee 6).

This suggested that the interviewee perceived that Australian academic standards are lower than those in Korea and therefore children who studied in Australia would fall behind 
Korean academic standards and when they returned to Korea would not be at the same level as their peers. The host country's education system was an influential factor for accompanying children for three expatriates. Although for Interviewee 2 developing his personal career was the most important factor, one of the next most important factors was the host country education system. Interviewee 5 agreed by saying that although children's education influenced his decision, the company did not consider the individual's willingness when making decisions about assignments.

An assignment was perceived more positively when the accompanying children are young. Younger children would benefit from relocating overseas as many Korean parents send their children to study English. However, if the children are in high school then there could be dilemmas in regards to university and adjustment issues. In situations where the children are at high school, expatriates choose to go overseas on their own. Given the possibility of this situation, Interviewee 8 said:

"If I had a choice I wouldn't expatriate. I'd rather be with my family." (Interviewee 8).

However, he said he would have to go overseas nevertheless as he does not have the choice to refuse an expatriate assignment when required by his company.

Additionally, location was perceived as important by five of the expatriates (Interviewees 1, 2, 5, $6 \&$ 9) and the major issues discussed were children's education, lifestyle, proximity of facilities, and safety of the host country. Interviewees 1,2 and 5 stressed that these issues were particularly important due to having accompanying family. Interviewee 5, however, commented that:

"The location of the expatriate assignment is important to my willingness on the international assignment. There are preferences for countries. For example I would not want to go to a country that wasn't safe. Nevertheless I would have to go. The country's economy, lifestyle and children's education will have slight influence but in the end it's the decision of the company." (Interviewee 5). 
Relocation was said to be a difficult experience for most of the trailing spouses. Although the children were able to live effectively in Australia within the first six months of starting school, most spouses indicated they had difficulties with cultural differences, loneliness, lack of information and language barriers. Only one spouse did not experience many difficulties adjusting to Australia as she already had previous international experience. Most of the spouses received assistance from the church they attended. As one spouse interviewee commented:

"Living abroad with only my husband to rely on and no other friends and relatives made it difficult and lonely...... It was especially difficult when I had my child and there was no one to talk to or receive help from. I was very fortunate to have the members of the church help me." (Interviewee 13 - Spouse).

When asked whether the company provided support for the spouse and the children, all spouses responded that they did not receive any particular help. They only received assistance with housing and learning English. Employment assistance for spouses was also not provided. The spouses did not specify the jobs they had undertaken in Korea prior to being posted, although there was some indication of administrative positions rather than senior professional roles. The spouses did suggest that giving up work was not a concern as their primary focus was on caring for their children. Most of the spouses suggested ways in which their husband's company could assist their experience in Australia, including language training and information sessions in relation to culture and lifestyle. One spouse commented that Korean companies needed to adapt to Western systems:

"I think the companies need to take into consideration the welfare and treatment of employees and their families working abroad for their company...... Just looking at Australian expatriates going into Korea you can see that the treatment differs to that received by Korean expatriates coming to Australia. The companies research into the costs of living, living environment, children's education system and etc so that the employee and their families can enjoy the same standard of living to when they were living in Australia." (Interviewee 13 -Spouse). 


\section{Conclusions and Discussion}

This section discusses the results in relation to both Korean and Western literature and highlights some of the special features of the Korean expatriation experience.

\section{Willingness of this cohort of Korean employees to expatriate}

Although the themes identified in this study suggest several issues are important to Korean employees and their spouses when deciding to accept an international assignment, it is clear that regardless of their personal willingness, they will eventually expatriate if required due to company loyalty and job security. Furthermore, it seems these expatriates will repatriate to Korea and their current company. This supports the existing literature that Korean employees are willing to expatriate and repatriate based on cultural values of high power distance (Shik, 2004; Kim and Kim, 2007), collectivism (Gray and Marshall 1998; Yang 2006) and Confucian characteristics (Paik and Sohn 1998; Kim and Park, 2003; Yang 2006). Although Rhee (2002) argued that individualistic characteristics are apparent amongst Korean employees, this research found that most of these expatriates, who were in their forties and fifties, displayed characteristics that placed significant importance on the needs of the company rather than their own individual needs or interests, thus supporting the Korean literature which suggests that older employees value job security and stability (Kim and McLean, 2008). The spouses in turn placed importance on their children and husband.

It should be noted though that despite willingness to do as requested by their organisations as being a major reason for accepting an expatriate assignment and repatriating when required, some interviewees did highlight other reasons for expatriation and noted that they may not actually be rewarded for taking the assignment abroad. While there was a diversity of opinions in respect to whether the international experience would result in promotion or gaining of performance points on repatriation, several of the expatriates did 
highlight career development. It might be expected that most saw the career development as related to security of employment with their current employer. Yet, one expatriate referred to the general value of international experience and one expatriate and one spouse were not keen to be repatriated to Korea which suggests that, even within this culture which emphasises loyalty to the organisation, there were some interviewees which might be regarded as being more focused on the concept of a boundaryless career beyond one organisation or location (see Tung, 1998b) and developing their own career capital (see Suutari \& Makela, 2007) particularly if the international experience was devalued or not rewarded by their current organisation. Indeed, these interviewees may recognise what Stahl, Miller and Tung (2002) highlight as the intrinsic value of the overseas experience per se with its opportunities for broad personal development (as was mentioned by one interviewee) as well as improvement in professional skills for career enhancement.

\section{Organisational repatriation training and mentoring for this cohort of Korean expatriates}

Significantly, the current research identified that repatriation training and mentoring support were not influencing factors for these Korean employees, partly due to the absence of these programs and the expatriates being unaware of their existence. The lack of influence of such programs was also partly due to their perception that advanced technology and flow of communication bridges the gap between home and host countries. This contrasts with existing literature on Western (Borstorff et al. 1997; Lazarova and Cerdin 2007) and Korean (Rhee 2002; Kim 2005) employees' perception of repatriation support. Online portals and intranet systems that work to build a database for expatriate employees may be replacing traditional face-to-face training and mentoring in Korean companies, assisting both work and non-work adjustment. The high uncertainty avoidance characteristics of Korean society indicate reluctance to accept ambiguity and change (Hofstede and Bond 1988), although it is 
suggested that risk taking behaviour increases within groups (Kim and Park, 2010; The Economist, 2011) . Yet, whilst the Korean literature focused on the employer-employee relationship it failed to acknowledge the extent to which advanced technology and online communication affect Korean employees' uncertainty avoidance. Furthermore, Korea is an internet savvy society and prefers the convenience of working with technology (Hwang and Yoo 2007) which may be another reason why Korean employees do not feel the need for traditional face-to-face training and mentoring. However, it might also be suggested that Confucian values which obligate the superior to inform subordinates about the goals of the company and the role of the employee and expectation of fulfilment of the role (see Chen \& Chung, 1994) translate into an informal mentoring of the expatriates, at least in respect to technical aspects of the assignment. This is consistent with research by Chang, Chang and Jacobs (2009) which argues that Korean organisations have strong military cultures where seniors are responsible for the learning of junior employees and that this is irrespective of formal mentoring programmes. Thus, formal mentoring that is utilised in the Western context may not be as necessary for Korean expatriates.

As noted though it should be acknowledged that given the importance of superiorsubordinate relationships, hierarchy and power distance in Korea (see Kim and Park, 2003; Yang, 2006), the Western concept of mentoring in organisations between peers or from subordinate to superior is unlikely to occur amongst Korean employees even when working on assignments in Western countries.

Importantly, the notion of returning to where I originally came from is strong in Korean society. Most of the expatriates did not recognise the need to be trained and mentored when they were returning to home, company and department. The spouses were excited about returning to friends and family. It may be that given Korean people's reluctance to change, the organisational culture and working environment in the host country subsidiary is 
influenced greatly by head office organisational culture and therefore differences in the working environments are minimal.

The Western literature states that difficulties in adapting to the home culture when repatriating can lead to reverse culture shock (Hurn 1999). However, this concern was not evident for this study of Koreans, as they did not expect any difficulties in the process of 'returning to where I originally came from'. As a majority of the interviewees have not been on an international assignment and repatriated, it may be that they do not yet understand reverse culture shock. However, concerns for the accompanying children's ability to readjust to Korea after being educated in Australia for several years did emerge. This indicates the need for companies to acknowledge and address children's ability to culturally adapt in repatriation.

The expatriates did not experience too many difficulties adjusting to Australia, but the spouses were more concerned than the expatriates with cultural training. This indicates that although work environments may be similar internationally, it is the non-work environment that may be considerably different - especially for the trailing spouse - and culture shock may be prominent amongst the expatriates' spouses. In this regard there appears to be little difference from Western literature.

\section{Career advancement for this cohort of Korean expatriates}

This study found that going on an international assignment may not always positively influence the expatriate's career advancement and thus supports existing Western literature (Gomez-Maija and Balkin 1987; Black and Gregersen 1991; Caligiuri and Lazarova 2001; Egan, Bendick and Miller 2002). This study indicated that these Korean employees generally did not perceive career advancement to be correlated with international assignments. Rather, the major reason behind their decision to expatriate was because of a company request. . This 
fits with Hofstede and Bond (1988) categorising Korea as a Confucian-based culture which requires employees to be obedient to their employer (Rhee 2002). Developing a career generally refers to career progression or promotion in the Western literature. In the Korean context it refers to having a secure occupation. This typical focus on employment security is evidenced by Korean government policy responses to mass unemployment following the foreign currency crisis in 1997 (Lee 2002). Additionally, there is still much more focus on long term loyalty and allegiance to the employer (Kim and Park, 2003). Therefore it is likely that it would not occur to most Koreans (whether or not they had prior experience of repatriation programs) that after an international assignment they may choose not to repatriate with their organisation but instead seek to stay in the country they had been assigned to (if possible) or gain employment with another organisation either in Korea or elsewhere. Some of the expatriates placed importance on whether the assignment would develop occupational security by enriching their current jobs to reach organisational goals. Therefore, whilst the Korean expatriates did not perceive career advancement to have a strong relationship to an international assignment, expectations of developing job security through successfully completing the assignment appeared to be significant for some.

\section{Family and spouse support for this cohort of Korean expatriates}

While one expatriate's wife remained in Korea in what might be referred to as a long distance 'commuter marriage' (see Gerstel \& Gross, 1984), the remainder of the expatriates had trailing spouses i.e. wives that did not work during the expatriate's posting. Research on Western trailing spouses has suggested that a major reason for expatriate failure is an inability of a trailing spouse to culturally adjust to the host country (Bauer \& Taylor, 2001). Further, it has been argued that impact on a spouse's career provides reason not to accept an assignment (see Bauer \& Taylor, 2001; De Cieri, Dowling \& Taylor, 1991). Although the 
spouses in the current research did suggest that they were experiencing some cultural challenges, their main concern in respect to the assignment was for the wellbeing of their children and the family being 'together'. The trailing spouses were more focused on raising their children and supporting their husbands than finding a job in Australia; with their employability also being affected by their lack of language competencies. Furthermore, the expatriates and spouses suggested that there was no spouse support provided by the companies in respect to finding work. Even though Makela, Kansala and Suutari (2011) have advised that spousal support is much more important in an international work context than in a domestic situation, research has highlighted the difficulties for the trailing spouse (in dual career couples) in finding work in the host country (Harvey, Novicevic \& Breland, 2009)

Yet, the findings in regard to Korean spouses in this study fit with literature which suggests that Confucian values, such as those in Korea, emphasise family loyalty and piety (Taormina 1998), and the father's decisions are valued by family members (Jaw et al. 2007) which contrasts with Western research which has argued for the importance of involving spouses in expatriate selection and support decisions (Riusala \& Suutari, 2000). Expatriate employees in Korea are rarely women (Kang and Rowley 2005). Moreover, when a man has decided to take an international assignment, the family will follow without questioning his decision (Park and Cho 1995). The current study reflected the Korean literature as all expatriates were male and all but one were accompanied by family. Further, the results generally support the men's predominant position within the family. Whilst some literature also identifies an increase in the number of women in Korea's workforce (Byun et al. 2001) and an increase in dual-income families (Kang and Rowley 2005) these Korean studies were not supported by the current research.

Contributions, implications and issues for future research The overarching focus of this research was exploring factors influencing Korean employees' and spouses' willingness to 
accept and repatriate from international assignments. Repatriation support policies do not appear to be factors that influence Korean expatriate employees' willingness. This is in part because they are not provided by the studied companies and in part because other factors appear to have more influence. However, certain new issues of significance, especially the utility of the internet for communication and information dissemination and children's cultural adaptability and education, were identified to be major factors for the Korean expatriates and their spouses and extend the literature on expatriation.

\section{Contributions}

A contribution of this research is broadening understanding of (largely Western) expatriate experiences to examining the attitudes that Korean expatriates and spouses have toward relocation. Importantly, the research has identified that experiences and attitudes towards relocation to an industrialised, English-speaking country (such as Australia) is perceived as significantly different from assignments to developing/emerging markets and non-English speaking countries; which adds to our understanding of the perceived value of expatriate assignments to particular locations.

Moreover, the findings suggest that perceptions of the Korean expatriate employees and spouses in this study do not necessarily correspond in all respects with existing Korean or Western literature. The Korean literature suggests that prior communication of training and mentoring support (Rhee 2002; Kim 2005), career advancement (Rhee 2002; Hwang 2006; Kim 2009), and family adjustment support (Dupuis et al. 2008) will influence employees' decision to expatriate. Much of this theory has been derived based on beliefs about Confucian values in Korea, stressing the importance of the employee-employer relationship (Paik and Sohn 1998; Rhee 2002; Yang 2006) and family-focused characteristics (Park and Cho 1995; Taormina 1998; Jaw et al. 2007). Uncertainty avoidance is also said to be strong in Korea 
(Hofstede and Bond, 1988) - although risk taking may be more prevalent in groups (Gannon and Pillai, 2010) - resulting in the assumption that prior communication of the support provided by the company may reduce levels of uncertainty and thus positively influence Korean employees' decision to expatriate (Kim 2005).

The existing literature may have neglected to identify the extent to which employeeemployer values control Korean employees' decisions. This small study is significant, however, in recognising that whilst there are numerous reasons that seem important to Korean employees, irrespective of these reasons a majority of employees may accept the assignment despite an apparent lack of training and mentoring support, no guarantee of career advancement and no family adjustment programs when repatriating. However, importantly, while only a few interviewees expressed reluctance to repatriate and emphasised career development and the value of the international experience, this potentially represents the emergence of an interest in boundaryless careers amongst Korean employees; suggesting this concept may be extended to a Korean context.

Additionally, the current study contributes to the literature by highlighting the reliance of Korean employees on online information and advanced technology when preparing for the assignment and seeking support to assist with cultural differences in expatriation and repatriation. Given that Korea is a country with strong advances in technology and is an internet-focused society, it is likely that there will be increased reliance on technology by Korean companies. This extends the literature on expatriate preparation, which has emphasised the role of organisational training and support primarily in relation to work adjustment, to a focus on the increasing importance of individual expatriate preparation through technology for both work and non-work aspects. The final contribution is in that the research identifies concerns about children's repatriation. Whilst existing Western literature focuses mainly on issues of repatriating the expatriate and the trailing spouse, limited 
discussion has been undertaken of the impacts of relocation on children. The findings of this research suggest that a major concern for these Korean expatriates was their children's cultural adaptability, particularly in respect to their education. This may indicate that although the authority lies with the husband in Korean families, focus was also placed on the wellbeing of the children.

\section{Implications for Korean organisations}

Relative to competitor organisations Korean companies which pay more attention to spouse and child cultural adaptability issues will likely achieve a competitive advantage in attracting employees who have an interest in undertaking international assignments; particularly Generation Y employees who may be more focused on boundaryless careers and hence more mobile across organisations. In order to not only attract but also retain such employees and their international knowledge and experience, Korean organisations might seek to provide spouse assistance in the new country and help the expatriate with obtaining a visa that will allow the expatriate and their family to remain in the host country until their children complete their education. Additionally, as the comments of interviewees in this study suggest that online training and database information for expatriates and their families may substitute for traditional face-to-face training, it may be advisable for Korean organisations to require expatriates to record their experiences and observations about cultural adaptability to a new country in a centrally accessible, online forum. Newly designed expatriate/repatriate support systems utilising technology may be utilised in the near future, and Western organisations might follow Korea's lead in this regard.

\section{Limitations and issues for further research}


As with all research there are opportunities to improve and extend the current study. This exploratory research was limited to a qualitative approach using semi-structured interviews with two groups of interviewees, namely, Korean expatriates working in Australia and their spouses. The interviewees all had similar demographic backgrounds and may not represent the diversity of Korean expatriates. Whilst only expatriate employees and spouses were interviewed, collecting data from expatriates' superiors would allow for triangulation. The views of trailing Korean spouses who give up work to accompany their partner on international assignments could be explored in more depth with respect to issues of whether they would like to work in Australia, any options or assistance they might have in finding jobs, and any organisational spousal programs.

We do acknowledge that the sample is small but we also suggest that the total number of Korean expatriate employees in Australia available and willing to participate in such research is also small. While it is difficult to gain 'insider' access to Korean business, subsequent research could operationalise this exploratory study in a large-scale, quantitative survey.

This study may be further developed by a number of interesting international comparisons given that a strength but and also a limitation of this research is that it only identified the experiences of Korean expatriates and their spouses in a developed, Englishspeaking country. Thus, it would be valuable to provide comparisons of management of Korean expatriates with management of foreign expatriates working in Korea, or to compare Korean and other nations' expatriates, such as from the United States, in one country, such as Australia. Future research could also include Korean expatriates who are working in other countries, such as Japan. Comparing Korean expatriates with another Confucian country, such as China, could indicate if there are similarities and differences in expatriate management across countries which have Confucian values. Researching Korean expatriates 
who are posted to non-English speaking emerging markets could further identify the value (indicated in this research) that Korean employees place on being assigned to an Englishspeaking, developed nation relative to a non-English speaking, emerging market posting.

It may be valuable to follow up with longitudinal research by re-interviewing the expatriate employees and spouses after they repatriate in order to compare their perceptions of repatriation with their satisfaction with the actual repatriation process. Finally, studying Korean employees in Korea who have yet to experience an international assignment would develop more understanding about what factors are influential before they accept an assignment, in contrast to this research where the interviewees had already expatriated. 


\section{References}

Andreason, A.W. (2003), 'Expatriate adjustment to foreign assignments', International Journal of Commerce and Management, 13(1), 42-49.

Aryee, J., Chay, Y.W., and Chew, J. (1996), 'The motivation to mentor among managerial employees: An interactionist approach', Group and Organisation Management, 21(3), 261-277.

Avril, A.B., and Magnini, V.P. (2007), 'A holistic approach to expatriate success', International Journal of Contemporary Hospitality Management, 19(1), 53-64.

Baugh, S., and Sullivan, S.E. (2005), 'Mentoring and career development', Career Development International, 10(6/7), 425-428.

Bauer, T. N., and Taylor, S. (2001). 'When managing expatriate adjustment, don't forget the spouse', The Academy of Management Executive, 15(4), 135-137.

Birkinshaw, J., Brannen, M.Y., and Tung, R L. (2011). 'From a distance and generalizable to up close and grounded: Reclaiming a place for qualitative methods in international business', Journal of International Business Studies, 42, 573-581.

Black, J.S., and Gregersen, H.B. (1991), 'When Yankee comes home: Factors related to expatriate and spouse repatriation adjustment', Journal of International Business Studies, 22(7), 617-634.

Black, J.S., Gregersen, H.B., and Mendenhall, M.E. (1992), 'Toward a theoretical framework of repatriation adjustment', Journal of International Business Studies, 23(4), 737-760.

Bonache, J. (2005), 'Job satisfaction among expatriates, repatriates and domestic employees: The perceived impact of international assignments on work-related variables', Personnel Review, 34(1), 110-124. 
Bonache, J., and Fernandez, Z. (1997), 'Expatriate compensation and its link to the subsidiary strategic role: A theoretical analysis', The International Journal of Human Resource Management, 8(4), 457-475.

Borstorff, P.S., Harris, S.G., Field, H.S., and Giles, W.F. (1997), 'Who'll go? A review of the factors associated with employee willingness to work overseas', Human Resource Planning, 20(3), 29-40.

Bossard, A., and Peterson, R. (2005), 'The repatriate experience as seen by American expatriates', Journal of World Business, 40(1), 9-28.

Brett, J.M., and Stroh, L.K. (1995), 'Willingness to relocate internationally', Human Resource Management, 34, 405-424.

Brislin, R.W. (1980), 'Translation and content analysis of oral and written material', In Handbook of cross-cultural psychology, ed. H.C. Triandis and J.W. Berry, Boston: Allyn and Bacon, 398-444.

Brookfield Global Relocation Services (BGRS). (2010), Global Relocation Trends: 2010 Survey Report. Woodridge: Brookfield Global Relocation Services.

Brookfield Global Relocation Services (BGRS). (2011), Global Relocation Trends: 2011 Survey Report. Woodridge: Brookfield Global Relocation Services.

Byun, H.S., Baek, K.H., and Kim, H.J. (2001), A Study on Changes of Korean Family and the Status and Role of Women. Accessed 16 ${ }^{\text {th }}$ October 2011 from http://www.kwdi.re.kr/reportView.kw? $\underline{s g r p}=$ SO1 andsiteCmsCd=CM0001andtopCmsCd=CM0002andcmsCd=CM0004andpnu $\underline{m=1 \text { andcnum }=0 \text { andnt } N o=309}$

Caligiuri, P., and Lazarova, M. (2001), 'Strategic Repatriation Policies to Enhance Global Leadership Development', In Developing Global Business Leaders: Policies, 
Processes, and Innovations, ed. M.E. Mendenhall, T.M. Kuhlmann and G.K. Stahl, Westport: Quorum Books, pp. 243-256.

Carraher, S.M., Sullivan, S.E., and Crocitto, M.M. (2008), 'Mentoring across global boundaries: an empirical examination of home- and host-country mentors on expatriate career outcomes', Journal of International Business Studies, 39, 1310-1326.

Chafkin, M. (2011). 'The returnees', Inc Magazine, Accessed 25 ${ }^{\text {th }}$ May 2012 from http://www.inc.com/magazine/201112/the-returnees_pagen_3.html

Chang, J., Chang, W., and Jacobs, R. (2009). 'Relationship between participation in communities of practice and organizational socialization in the early careers of South Korean IT employees', Human Resource Development International, 12(4), 407-427.

Chen, H.F., and Chiu, Y.H. (2009), 'The influence of psychological contracts on the adjustment and organizational commitment among expatriates', International Journal of Manpower, 30(8), 797-814.

Chen, G-M., and Chung, J. (1994). 'The impact of Confucianism on organizational communication', Communication Quarterly, 42(2), 93-105.

Choi, D.S., Michell, P., and Palihawadana, D. (2008), 'Exploring the components of success for the Korean chaebols', The Journal of Business \& Industrial Marketing, 23(5), 311322.

Collings, D.G. Scullion, H., and Morley, M.J. (2007), 'Changing patterns of global staffing in the multinational enterprise: Challenges to the conventional expatriate assignment and emerging alternatives', Journal of World Business, 42(2), 198-213.

Crowne, K.A. (2009), 'Enhancing knowledge transfer during and after international assignments', Journal of Knowledge Management, 13(4), 134-147. 
De Cieri, H., Dowling, P., and Taylor, K., (1991). 'The Psychological Impact of Expatriate Relocation on Partners', The International Journal of Human Resource Management, 2(3), 377-414.

Department of Foreign Affairs and Trade (DFAT) Australia. (2011), Republic of Korea country brief. Accessed $14^{\text {th }}$ May 2011 from http://www.dfat.gov.au/geo/rok/brief_index.html

Dicicco-Bloom, B., and Crabtree, B.F. (2006), 'The qualitative research interview', Medical Education, 40(4), 314-321.

Doherty, N., Dickmann, M., and Mills, T. (2011), 'Exploring the motives of company-backed and self-initiated expatriates', The International Journal of Human Resource Management, 22(3), 595-611.

Doz, Y. (2011), 'Qualitative research for international business', Journal of International Business Studies, 42, 582-590.

Dupuis, M.J., Haines, V.Y., and Saba, T. (2008), 'Gender, family ties, and international mobility: cultural distance matters', The International Journal of Human Resource Management, 19(2), 274-295.

Egan, M., Bendick, M., and Miller, J. (2002), 'US firms' evaluation of employee credentials in international business', International Journal of Human Resource Management, 13, 76-88.

Feldman, D.C., and Thomas, D.C. (1992), 'Career management issues facing expatriates', Journal of International Business Studies, 23(2), 271-293.

Gannon, M., and Pillai, R. (2010). Understanding global cultures: Metaphorical journeys through 29 nations, clusters of nations, continents, and diversity, $4^{\text {th }}$ edn., Thousand Oaks: Sage. 
Gerstel, N., and Gross, H. (1984). Commuter marriage. A study of work and family, New York: Guilford Press.

Gillian, F. (1996), 'Heck no - we won't go', Personnel Journal, 75(3), 37-43.

Gomez-Meija, L.R., and Balkin, D.B. (1987), 'The determinants of managerial satisfaction with the expatriation and repatriation process', Journal of Management Development, 6, 7-18.

Gray, K.R., and Marshall, K.P. (1998), 'Kenyan and Korean management orientations on Hofstede's cultural values', Multinational Business Review, 6(2), 79-88.

Gregersen, H.B., and Stroh, J.K. (1997), 'Coming home to the arctic cold: antecedents to Finnish expatriate and spouse repatriation adjustment', Personnel Psychology, 50(3), $635-654$.

Haines III, V.Y., and Saba, T. (1999), 'Understanding reactions to international mobility policies and practices', Human Resource Planning, 22(3), 40-52.

Harvey, M., Novicevic, M., and Breland, J.W. (2009). 'Global dual-career exploration and the role of hope and curiosity during the process', Journal of Managerial Psychology, 24(2), 178-197.

Harvey, M., and Wiese, D. (1998), 'Global dual-career couple mentoring: a phase model approach', HR Human Resource Planning, 21(2), 33-48.

Haslberger, A., and Stroh, L.K. (1992), 'Be prepared: Development and selection of expatriates', Human Resources Development Quarterly, 6(3), 287-292.

Hesse-Biber, S.N., and Leavy, P. (2011), The practice of qualitative research, Los Angeles: Sage.

Hinsz, V.B., and Nelsen, L.C. (1990), 'Testing models of turnover intentions with university faculty', Journal of Applied Social Psychology, 20(1), 68-84. 
Hofstede, G. (1980), Culture's consequences: International differences in work-related values, Beverly Hills: Sage.

Hofstede, G., and Bond, M.H. (1988), 'The Confucius connection: From cultural roots to economic growth', Organizational Dynamics, 16(4), 5-21.

Hurn, B.J. (1999). 'Repatriation-the toughest assignment of all', Industrial and Commercial Training, 31(6), 224-228.

Hwang, E. (2006), A multilevel test of fear of crime: the effect of social conditions, perceived community policing activities, and perceived risks of victimization in a megalopolis (Unpublished dissertation). East Lansing, Michigan: Michigan State University.

Hwang, J., and Yoo, J. (2007). A study on changing trends and causes of internet usage in everyday life: a comparison between 2002 and 2005. Informatization Policies, 14(1), $19-43$.

Hyder, A.S., and Lovblad, M. (2007), 'The repatriation process - a realistic approach', Career Development International, 12(3), 264-281.

Jassawalla, A., Connelly, T., and Slojkowski, L. (2004), 'Issues of effective repatriation: A model of managerial implications', S.A.M. Advanced Management Journal, 69(2), 38-46.

Jaw, B.S., Ling, Y.H., Wang, C.Y.P., and Chang, W.C. (2007), 'The impact of culture on Chinese employees' work values', Personnel Review, 36(1), 128-144.

Kamoche, K. (1997), 'Knowledge creation and learning in international HRM', The International Journal of Human Resource Management, 8(3), 213-225.

Kang, H.R., and Rowley, C. (2005), 'Women in management in South Korea: Advancement or retrenchment?', Asia Pacific Business Review, 11(2), 213-231.

Kim, O.H. (2005), 'A study on corporate strategy to enhance the organizational adjustment capability of the repatriates in global time', Korean Management Bulletin, 18(5), 22312255. 
Kim, N.H., and McLean, G.N. (2008), 'Stability and dominance in career success orientation in South Korean employees'. Human Resource Development International, 11(1), 19-34.

Kim, A.E., and Park, G.S. (2003), 'Nationalism, Confucianism, work ethic and industrialization in South Korea'. Journal of Contemporary Asia, 33(1), 37-49.

Kim, E.H., and Kim, W. (2007), 'Corporate governance in Korea: A decade after the Asian financial crisis'. The University of Texas School of Law, Law and Economics Research Paper No. 123.

Kim, D-Y., and Park, J. (2010). 'Cultural differences in risk: The group facilitation effect', Judgement and Decision Making, 5(5), 380-390.

Konopaske, R., and Werner, S. (2005), 'US managers' willingness to accept a global assignment: Do expatriate benefits and assignment length make a difference?', The International Journal of Human Resource Management, 16(7), 1159-1175.

Kraimer, M.L., Shaffer, M.A., and Bolino, M.C. (2009), 'The influence of expatriate and repatriate experiences on career advancement and repatriate retention', Human Resource Management, 48(1), 27-47.

Larson, D. (2006), 'Here we go again: How a family's cross-cultural and repatriation adjustment relates to the employee's receptivity to future international assignments' Advanced Management Journal, 71(2), 46-57.

Lazarova, M.B., and Cerdin, J.L. (2007), 'Revisiting repatriation concerns: Organizational support versus career and contextual influences', Journal of International Business Studies, 38(3), 404-429.

Lee, H.W. (2005), 'The factors influencing expatriates', Journal of American Academy of Business, 6(2), 273-278. 
Lee, J.Y. (2002), Policies for information, guidance and counselling services: National questionnaire for Korea, OECD. Accessed 24 $4^{\text {th }}$ February 2012 from http://www.oecd.org/dataoecd/52/58/2500594.pdf

Lee, T. W. (1999), Using qualitative methods in organizational research, Thousand Oaks:

Sage.

Leiba-O'Sullivan, S.L. (2002), 'The protean approach to managing repatriation transitions', International Journal of Manpower, 23(7), 597-616.

MacDonald, S., and Arthur, N. (2005), 'Connecting career management to repatriation adjustment', Career Development International, 10(2), 145-158.

Mah, J.S. (2007), 'Industrial policy and economic development: Korea's experience', Journal of Economic Issues, 41(1), 77-92.

Makela, L., Kansala, M., and Suutari, V. (2011), 'The roles of expatriates' spouses among dual career couples', Cross Cultural Management: An International Journal, 18(2), 185-197.

Maxwell, J.A. (2005), Qualitative research design: An interactive approach, $2^{\text {nd }}$ ed., Thousand Oaks: Sage.

Minbaeva, D.B., and Michailova, S. (2004), 'Knowledge transfer and expatriation in multinational corporations', Employee Relations, 26(6), 663-679.

Morden, T., and Bowles, D. (1998), 'Management in South Korea: A review', Management Decisions, 36(5), 316-330.

Paik, Y., and Vance, C.M. (2002), 'Evidence of back-home selection bias against US female expatriates', Women in Management Review, 17(2), 68-79.

Paik, Y.S., and Sohn, J.H. (1998), 'Confucius in Mexico: Korean MNCs and the Maquiladoras', Business Horizons, 41(6), 25. 
Park, I.H, and Cho, L.J. (1995), 'Confucianism and the Korean family', Journal of Comparative Family Studies, 26, 117-134.

Rhee, Y. (2002), 'Global public relations: A cross-cultural study of the excellence theory in South Korea', Journal of Public Relations Research, 14(3), 159-184.

Riusala, K., and Suutari, V. (2000), 'Expatriation and careers: perspectives of expatriates and spouses', Career Development International, 5(2), 81-90.

Sekaran, U., and Bougie, R. (2010), Research methods for business: a skill-building approach, Chichester: Wiley.

Selmer, J. (1999), 'Corporate expatriate career development', Journal of International Management, 5, 55-71.

Shik, K.B. (2004), 'Korean corporate culture and Malaysia's look East policy expectations', Malaysian Management Review, 39(1), 1-14.

Stahl, G.K., Chua, C.H., Caligiuri, P., Cerdin, J.L., and Taniguchi, M. (2009), 'Predictors of turnover intentions in learning-driven and demand-driven international assignments: The role of repatriation concerns, satisfactions with company support, and perceived career advancement opportunities', Human Resource Management, 48(1), 89-109.

Stahl, G.K., Miller, E.L., and Tung, R.L. (2002), 'Toward the boundaryless career: A closer look at the expatriate career concept and the perceived implications of an international assignment', Journal of World Business, 37(3), 216-227.

Suutari, V. (2003), 'Global managers: Career orientation, career tracks, life-style implications and career commitment', Journal of Managerial Psychology, 18, 185-207.

Suutari, V., and Brewster, C. (2003), 'Repatriation: Empirical evidence from a longitudinal study of careers and expectations among Finnish expatriates', The International Journal of Human Resource Management, 14(7), 1132-1151. 
Suutari, V., and Mäkelä, K. (2007), 'The career capital of managers with global careers', Journal of Managerial Psychology, 22(7), 628-648.

Taormina, R.J. (1998), 'Employee attitudes towards organizational socialization in the people's Republic of China, Hong Kong, and Singapore', The Journal of Applied Behavioral Science, 34(4), 468-485.

Tharenou, P. (2003), 'The initial development of receptivity to work abroad: Self initiated international work opportunities in young graduate employees', Journal of Occupational and Organizational Psychology, 76, 489-515.

The Economist. (2011), 'South Korean entrepreneurs: Young, gifted and blocked: Korea needs fewer wage slaves and more entrepreneurs', The Economist, Accessed $25^{\text {th }}$ May 2012 from http://www.economist.com/node/18682342

Tung, R.L. (1998a), 'A contingency framework of selection and training of expatriates revisited', Human Resource Management Review 8(1), 23-37.

Tung, R.L. (1998b), 'American expatriates abroad: From neophytes to cosmopolitans', Journal of World Business, 33(2), 125-144.

Van der Heijden, J., van Engen, M., and Paauwe, J. (2009), 'Expatriate career support: predicting expatriate turnover and performance', The International Journal of Human Resource Management, 20(4), 831-845.

Van der Zee, K.I., Ali, A.J. and Salome, E. (2005), 'Role interference and subjective wellbeing among expatriate families', European Journal of Work and Organizational Psychology, 14, 239-262.

Vidal, M.E.S., Valle, R.S., and Aragon, M.I.B. (2008), 'International workers' satisfaction with the repatriation process', The International Journal of Human Resource Management, 19(9), 1683-1702. 
Ward, C., and Kennedy, A. (1996), 'Crossing cultures: the relationship between psychological and socio-cultural dimensions of cross-cultural adjustment', In Asian Contributions to Cross-Cultural Psychology ed. J. Pandey, D. Sinha, and D.P.S, Bhawuk, New Delhi: Sage, 289-306.

Wiesner, W.H., and Cronshaw, S.F. (1988), 'A meta-analytical investigation of the impact of interview format and degree of structure on the validity of the employment interview', Journal of Occupational Psychology, 61(4), 275-290.

Woo, P.C., and Ang, S.H. (2011), 'The impact of expatriate supporting practices and cultural intelligence on cross-cultural adjustment and performance of expatriates in Singapore', The International Journal of Human Resource Management, 22(13), 2683-2702.

Wood, E.D., and El Mansour, B. (2010), 'Integrative literature review: Performance interventions that assist Chinese expatriates' adjustment and performance: Toward a conceptual approach', Human Resource Development Review, 9(2): 194-218.

Yan, A., Zhu, G. and Hall, D.T. (2002), 'International assignment for career building: A model of agency relationships and psychological contracts', Academy of Management Review, 27(3), 373-391.

Yang, I. (2006), 'Jeong exchange and collective leadership in Korean organizations', Asia Pacific Journal of Management, 23(3), 283-298.

Yin, R.K. (2011), Qualitative research from start to finish, New York: The Guilford Press. 
Table 1: Expatriate interviewee demographics

\begin{tabular}{|l|l|l|l|l|l|l|l|l|l|}
\hline Interviewee & $\mathbf{1}$ & $\mathbf{2}$ & $\mathbf{3}$ & $\mathbf{4}$ & $\mathbf{5}$ & $\mathbf{6}$ & $\mathbf{7}$ & $\mathbf{8}$ & $\mathbf{9}$ \\
\hline Age group & $40-49$ & $40-49$ & $40-49$ & $50+$ & $40-49$ & $30-39$ & $30-39$ & $40-49$ & $40-49$ \\
\hline Gender & Male & Male & Male & Male & Male & Male & Male & Male & Male \\
\hline $\begin{array}{l}\text { Highest level } \\
\text { of education }\end{array}$ & Masters & Bachelors & Bachelors & Masters & Masters & Bachelors & Bachelors & Bachelors & Masters \\
\hline Marital status & Married & Married & Married & Married & Married & Married & Married & Married & Married \\
\hline $\begin{array}{l}\text { Number of } \\
\text { children }\end{array}$ & 2 & 1 & 2 & 1 & 2 & 2 & - & 3 & 2 \\
\hline $\begin{array}{l}\text { Age of each child } \\
\text { years) }\end{array}$ & 5,3 & 7 & 14,13 & $20 \mathrm{~s}$ & 12,7 & 12,7 & - & $12,10,7$ & 21,18 \\
$\begin{array}{l}\text { Prior } \\
\text { international } \\
\text { experience }\end{array}$ & No & No & Yes & No & Yes & No & No & No & Yes \\
\hline
\end{tabular}


Table 2: Spouse interviewee demographics

\begin{tabular}{|l|l|l|l|l|l|l|}
\hline Interviewee & $\mathbf{1}$ & $\mathbf{2}$ & $\mathbf{3}$ & $\mathbf{4}$ & $\mathbf{5}$ & $\mathbf{6}$ \\
\hline Gender international & Female & Female & Female & Female & Female & Female \\
\hline $\begin{array}{l}\text { Prior } \\
\text { experience }\end{array}$ & No & No & Yes & Yes & No \\
\hline $\begin{array}{l}\text { Employed at time of } \\
\text { international } \\
\text { assignment request }\end{array}$ & No & Yes & No & Yes & No & Yes \\
\hline
\end{tabular}

